\title{
小微湿地研究综述: 定义、类型及生态系统服务
}

\author{
崔丽娟 ${ }^{1,2,3, *}$, 雷茵茹 ${ }^{1,2,3}$, 张曼胤 ${ }^{1,2,3}$, 李 伟 $1,2,3$ \\ 1 中国林业科学研究院湿地研究所, 北京 100091 \\ 2 湿地生态功能与恢复北京市重点实验室, 北京 100091 \\ 3 北京汉石桥湿地生态系统国家定位观测研究站, 北京 101399
}

摘要: 小微湿地作为一个“新兴” 的概念, 受到学者和政策制定者的日益关注。虽然小微湿地面积较小, 但是却发挥着独特的生 态功能。针对小微湿地的深人研究, 有助于进一步拓展湿地科学的研究尺度, 促进学科体系发展。介绍了小微湿地研究兴起的 背景, 总结了小微湿地的面积范围和分类体系, 归纳了小微湿地的累加作用和景观特征, 着重分析了小微湿地在维持关键物种 种群、提供生物迁移踏脚石、调节雨洪、改善水质, 以及营造城乡优美景观等方面提供的生态系统服务。提出未来需要进一步加 强小微湿地生态过程和相关机理研究, 将小微湿地建设与现行湿地保护体系和城乡生态环境建设有机结合, 促进小微湿地建设 的有序和可持续发展。

关键词: 小微湿地;面积范围;特征;分类系统;生态系统服务

\section{Review on small wetlands : definition, typology and ecological services}

\author{
CUI Lijuan ${ }^{1,2,3, *}$, LEI Yinru ${ }^{1,2,3}$,ZHANG Manyin ${ }^{1,2,3}$, LI Wei $^{1,2,3}$ \\ 1 Institute of Wetland Research, Chinese Academy of Forestry, Beijing 100091, China \\ 2 Beijing Key Laboratory of Wetland Services and Restoration, Beijing 100091, China \\ 3 Beijing Hanshiqiao National Wetland Ecosystem Research Station, Beijing 101399, China
}

\begin{abstract}
As an emerging concept, small wetlands obtain increasing global attention from scholars to policy-makers. Small wetlands provide the essential ecosystem services despite of their limited areas. Focusing on small wetlands can not only expand the research scale, but also promote the development of wetland research discipline. This paper introduced the background of small wetlands studies, generalized the definition and classification of small wetlands, and then concluded their cumulative impacts and landscape characteristics. Next the paper reviewed the varies and valuable ecological services provided by small wetlands, including maintaining critical habitats, providing migrating stepping stones, regulating hydrologic process, purifying contaminated water, and creasing pleasant urban and rural landscape. As a conclusion, we suggested that research on ecological process and function mechanism of small wetlands should be further strengthened in the future. Additionally, the construction and restoration programs of small wetlands should be integrated with current wetland conservation schemes and rural-urban ecological construction programs to promote their sustainable development.
\end{abstract}

Key Words : small wetlands; extent of area; characteristics; classification; ecological services

湿地是全球生物多样性最高的生态系统之一, 为人类的健康和福祉提供了多种生态系统服务。但是随着 工业和城市化发展, 全球湿地遭受了严重的破坏。1970 年至 2015 年间, 全球湿地面积减少了约 $35 \%$ 。如

基金项目: 中央级公益性科研院所基金(CAFYBB2017ZA002-5)

收稿日期: 2020-03-26; 网络出版日期:2021-01-04

* 通讯作者 Corresponding author. E-mail: lkyclj@126.com

http://www. ecologica. cn 
何遏制湿地的快速消失和退化,成为世界各国学者和政策制定者共同关心的重要议题之一。但相比之下,大 型湿地受到了更多的关注,也实施了更为完善的保护措施, 而面积较小的湿地, 却常常在现有的湿地保护体 系、保护名录和湿地资源调查中 “缺席” [2]。例如全球国际重要湿地的平均面积为 $106310 \mathrm{hm}^{2}$, 我国国家级湿 地类型自然保护区的平均面积为 $220500 \mathrm{hm}^{2[3-4]}$ 。湿地政策,例如美国施行的 “零净损失” 政策和湿地缓解银 行, 也曾倾向于通过恢复或者重建少量的大型湿地, 来弥补众多被占用和破坏的小型湿地 ${ }^{[5]}$ 。这些被忽略和 替代的小型湿地,其生态系统服务价值被严重低估,成为了隐形消失的自然资产。

自 20 世纪 60 年代起,美国、英国和爱尔兰等发达国家陆续开展了针对草原湖穴、池塘等小型湿地的生态 调查和保护恢复工作 ${ }^{[6-8]}$ 。我国小微湿地的研究正处于起步阶段,有少量文献介绍了小微湿地的概念、管理 和营造技术 ${ }^{[9-10]}$, 缺乏对小微湿地内涵、分类体系、生态特征和生态功能等的清晰界定和系统梳理。本文介绍 了小微湿地研究兴起的背景, 总结了小微湿地面积范围和分类体系, 梳理了小微湿地累加作用和景观特征, 并 着重分析了小微湿地在维护关键生物种群、提供生物迁移踏脚石、促进雨洪管理和水质提升, 以及营造城乡优 美景观等方面发挥的重要作用,以期为我国逐步兴起的小微湿地建设、恢复及保护提供科学参考。

\section{1 小微湿地的面积和特征}

以往的研究中出现过小型湿地 (small wetland)、小尺度湿地 ( small-scale wetlands)、小块湿地 (small patches of wetlands), 微型湿地 (micro wetlands)、迷你湿地 (mini-wetland)、湿地镶嵌体 (wetland mosaics) 等不 同名词 ${ }^{[2,11-13]}$ 。可以看出, 这些概念大部分都是强调湿地面积的“小”和“微”。面积是决定小微湿地生态特征 的核心要素之一。

\section{1 小微湿地的面积}

目前, 关于小微湿地的面积还没有清晰的范围界定。生态学家一般通过考虑局域种群所需的生境面积、 种群生存力等确定栖息地或者自然保护地的面积 ${ }^{[14]}$ 。在国内外开展的相关研究和湿地恢复实践中, 小微湿 地的面积根据其所保护的种群类型和功能, 从 $0.1 \mathrm{hm}^{2}$ 到几十 $\mathrm{hm}^{2}$ 不等( 见表 1), 其中 $1 \mathrm{hm}^{2}$ 左右的小微湿地 在维持爬行和两栖动物多样性上发挥了重要作用。

表 1 小微湿地的保护对象及其面积范围

Table 1 Conservation objects and areas of small wetlands

\begin{tabular}{|c|c|c|c|}
\hline 保护物种类型 & 面积 & 地点 & 相关研究 \\
\hline Protected species & Area & Location & Relevant research \\
\hline \multirow[t]{3}{*}{$\begin{array}{l}\text { 两栖动物/无脊椎动物 } \\
\text { Amphibian/invertebrate }\end{array}$} & $0.13-1.21 \mathrm{hm}^{2}$ & $\begin{array}{l}\text { 哥伦比亚和索克尔 } 11 \text { 块小型 } \\
\text { 湿地 }\end{array}$ & 爬行和两栖动物丰度最高 \\
\hline & $0.38-1.06 \mathrm{hm}^{2}$ & 美国南卡罗莱纳州 ${ }^{[16]}$ & $\begin{array}{l}\text { 小型湿地是维持研究区爬行类动物区系 } \\
\text { 丰富度的焦点 }\end{array}$ \\
\hline & $1 \mathrm{hm}^{2}$ 左右 & 美国东南部滨海湿地 ${ }^{[17]}$ & $\begin{array}{l}\text { 作为重要的受食资源和繁殖栖息地, 维持 } \\
\text { 着许多动物区系的复合种群结构 }\end{array}$ \\
\hline \multirow[t]{3}{*}{ 鸟类 Birds } & $0.08-10 \mathrm{hm}^{2}$ & $\begin{array}{l}\text { 美国北部草原壸穴 ( Prairie } \\
\text { Potholes) 区域 }\end{array}$ & $\begin{array}{l}\text { 草原嗑穴湿地是雁鸭类在迁徙途中重要 } \\
\text { 的停歇地 }\end{array}$ \\
\hline & $4 \mathrm{hm}^{2}$ 以下 & 美国东部沙丘湿地 [19-20] & $\begin{array}{l}\text { 美洲密西西比迁徙路线上水鸟春季集结 } \\
\text { 地、繁殖地、迁徙中转地和越冬地 }\end{array}$ \\
\hline & - & 博茨瓦纳马卡迪卡迪盐沼 ${ }^{[21]}$ & $\begin{array}{l}\text { 为火烈鸟 (Phoenicopterus Linnaeus) 提供重 } \\
\text { 要的受食地和迁徙中转地 }\end{array}$ \\
\hline 鱼类 Fish & $27 \mathrm{hm}^{2}$ & $\begin{array}{l}\text { 韩国首尔汉江小沙洲, 国际重 } \\
\text { 要湿地 }\end{array}$ & $\begin{array}{l}\text { 朝鲜鱊 ( Acheilognathus yamatsutae)、韩国 } \\
\text { 刺鳑鲏 (Acanthorhodeus gracilis) 等本地特 } \\
\text { 有种的产卵和育苗场所 }\end{array}$ \\
\hline \multirow[t]{2}{*}{ 植物 Plants } & $\begin{array}{l}17 \text { 个小于 } 0.8 \mathrm{hm}^{2}, 11 \text { 个小于 } \\
0.4 \mathrm{hm}^{2}, 7 \text { 个小于 } 0.2 \mathrm{hm}^{2}\end{array}$ & 欧洲岩溶洞穴湿地 ${ }^{[23]}$ & $\begin{array}{l}\text { 含钻和镁离子较高的岩溶洞穴湿地, 某些 } \\
\text { 罕见耐钙植物的生存场所 }\end{array}$ \\
\hline & $1 \mathrm{hm}^{2}$ 以下 & 波兰马苏利安湖的壶穴 ${ }^{[24]}$ & 支持 20 余个不同植物群落的生存 \\
\hline
\end{tabular}


政策制定者则是从湿地调查的精度或管理的角度来界定小微湿地的面积。例如,我国第二次全国湿地资 源调查的起调面积为 $8 \mathrm{hm}^{2[25]}$, 因此许多管理条例、办法将面积小于 $8 \mathrm{hm}^{2}$ 的湿地界定为小微湿地。随着湿地 调查技术的快速发展,许多国家和地区都在不断缩小湿地调查的起调面积。美国陆军工程兵团的湿地恢复法 案修订版将湿地起调面积由 $4 \mathrm{hm}^{2}$ 降低为 $1.2 \mathrm{hm}^{2[26]}$; 苏格兰制定的《池塘、水塘和小内湖: 苏格兰小水体管 理和建设的优秀实践指南》中将小于 $2 \mathrm{hm}^{2}$ 作为小型湿地的起调面积; 英国在 2007 年乡村普查中调查了 0.0025-2 $\mathrm{hm}^{2}$ 范围的池塘 ${ }^{[9]}$; 北京市在 2018 年启动的湿地资源调查中, 将湿地的起调面积进一步缩小为 $0.0667 \mathrm{hm}^{2[27]}$ 。

\section{2 小微湿地的特征}

\subsection{1 小微湿地的累加作用}

一般来说, 湿地生态系统功能与其面积大小密切相关。传统的景观生态学认为, 湿地面积在一定范围内 与物种的种类和数量显著相关, 面积越大的湿地具有更多样的生境, 可以维持更多的物种生存。随着岛屿生 物地理学理论与集合种群理论的发展, 相关研究表明小微湿地之间的连接性和目标物种的最小生境面积, 均 是影响小微湿地生态功能的重要因素 ${ }^{[28-29]}$ 。如果在一个大的地理区中拥有数量众多的小型湿地, 因为它们 的分布更广泛, 具有更多变的气候、土壤、地质和土地利用情况, 生境异质性更高 ${ }^{[15,30]}$, 因此在特定情况下比 同等面积的独立大型湿地发挥更重要的生态功能。

\subsection{2 小微湿地的景观特征}

小微湿地的斑块形状各异, 斑块内部和边缘区域的物质循环和能量流动存在较大差异。相比与大型湿 地, 同等面积的小微湿地通常具有更长的水陆岸线长度和生态交错区面积 ${ }^{[31]}$, 可增强某些特殊的生态过程。 同时, 小微湿地通常作为离散斑块存在于大型湿地之间, 可以作为物种迁移的 “踏脚石”, 尤其对一些迁移距 离不远的两栖动物和部分昆虫等提供关键栖息地, 同时也为某些湿地水鸟生命周期的特定阶段提供停歇地和 栖息地 ${ }^{[32]}$ 。有些小微湿地是地理上的孤立斑块, 能够为某些珍稀和隔离的物种提供庇护所, 促进分区物种的 形成 ${ }^{[33]}$ 。

\section{2 小微湿地的分类}

湿地生态系统结构复杂, 湿地类型在不同区域差异很大, 致使湿地存在多种分类系统。与湿地分类系统 相对应, 小微湿地也存在不同的分类方法。

\section{1 依据地理位置分类}

按照与大型湿地的位置关系, 小微湿地可以划分为 (1) 与大型湿地相联系的小微湿地, 以及 (2) 地理位置 上相对独立的小微湿地 (Geographically isolated wetlands, GIW)。前者因为与大型湿地同处于一个大的地理 区位, 属于大型湿地的附属部分, 因此类型也与大型湿地相对应, 如流域中的小型沼泽湿地, 河流滨水湿地, 天 然渗流区、水文通道沿岸的潮湿洼地、与排水区相连的沟渠等 ${ }^{[2]}$ 。这些小微湿地能够丰富大型湿地的生境类 型, 提高整个区域的生境异质性。后者是指与上下游水域缺乏明显地表水联系的一类小微湿地 ${ }^{[34]}$ 。Tiner 将 美国的小型独立湿地按照地理位置分为了 9 个不同类型,包括 (1) 大陆中部草原和草原盆地湿地,包括草原 壶穴、盐湖、雨水盆地湿地和沙丘湿地; (2) 半沙漠和沙漠盆地及平原湿地,包括盐湖、盐滩、河道疤地和沙漠 泉等; (3) 冰穴湿地; (4) 大西洋海湾沿岸平原盆地湿地, 包括德玛瓦半岛壸穴、卡罗莱纳州港湾和浅沼泽等; (5) 卡斯特盆地湿地,包括柏树穹顶和石灰石天坑等; (6) 春池湿地,包括西海岸春池和森林春池等; (7) 滨海 潮间带湿地; (8) 五大湖矮灌木湿地; (9) 不活跃的河漫滩湿地 ${ }^{[35]}$ 。这些小型湿地往往分布有一些独特的物 种,或者某些物种的亚种或变种等,成为独特的生境类型。

\section{2 依据水文周期分类}

小微湿地的水文周期, 包括积水的时间和泛洪的频率等。Boulton 和 Brock 依据水文周期将小微湿地分 为 5 类,包括 (1) 短暂型湿地, 只有在突发性暴雨和径流后存在,一段时间后自然消失, 只能支持少量水生生 
物短期存在; (2) 偶然型湿地, 10 年内大概有 9 年是干枯的,经历少量不规则的泛洪,保持湿润的时间持续几 个月, 大部分是陆生植物区系, 生长着少量水生植物, 有一些扩散能力强或抗旱能力高的动物存在; (3) 间歇 型湿地, 干湿交替存在, 但是淹水频率不太规则, 泛洪时间可能持续数月或数年, 水生植物在岸带生长, 有适宜 短期水体的动物生存, 也为其他动物提供繁殖或受食地; (4) 季节性湿地, 每年干湿交替存在, 在雨季保持湿 润,在旱季变干, 大部分植物和动物能够完成它们的生命周期; (5) 近永久型湿地, 规律性泛洪, 水位波动, 10 年内大概有 1 年是干枯的,生存的生物大部分都不具有耐旱性 ${ }^{[36]}$ 。这种分类方法在分析气候变化影响下,小 微湿地水文情势变化对其生态功能影响时具有独特的优势 ${ }^{[37]}$ 。

2.3 按照人为干扰影响程度分类

按照人为干扰影响程度划分, 小微湿地既包括自然演变形成的河流 (宽度一般在 $5 \mathrm{~m}$ 以下)、沟、荡、泡 沼、溪流、河浜、泉、潭等天然湿地; 也包括坑塘、养殖塘、陂塘、水田、城市景观水面、雨水湿地和净化湿地等人 工湿地。随着人类活动干扰加剧, 许多城市和农业用地周围的天然小微湿地在城市化进程中逐渐消失。人工 型小微湿地多根据人们需求, 以人工建造或者人工控制为主, 受人类活动影响大, 其净化、景观、休闲娱乐等社 会服务功能被显著增强。

2.4 按照主导生态系统服务分类

小微湿地受到面积的制约,通常不能发挥大型湿地所具有的完备的生态系统服务,但会发挥某种或某几 种主导功能。以主导的生态系统服务划分小微湿地, 更有利于体现出小微湿地的特点和功能, 也能更直接地 指导小微湿地的恢复和建设实践。表 2 列举了小微湿地提供的主导生态系统服务,但是这些主导生态系统服 务通常不是单一存在的。例如, 有时水质净化型小微湿地同时也是景观游憩型小微湿地和科普宣教型小微 湿地。

表 2 基于主导生态系统服务的小微湿地分类

Table 2 Classification of small wetlands according to their dominant ecosystem services

\begin{tabular}{|c|c|c|}
\hline $\begin{array}{l}\text { 类型 } \\
\text { Types }\end{array}$ & $\begin{array}{l}\text { 特征及功能 } \\
\text { Characteristics and ecosystem service }\end{array}$ & $\begin{array}{l}\text { 例子 } \\
\text { Examples }\end{array}$ \\
\hline $\begin{array}{l}\text { 水质净化型 } \\
\text { Water purification }\end{array}$ & $\begin{array}{l}\text { 通过基质、植物和微生物的协同作用,实现水质净化目标, 可用于深 } \\
\text { 度净化污水处理厂尾水,处理小规模、分散农村生活污水,减少面源 } \\
\text { 污染 }\end{array}$ & 人工处理湿地 \\
\hline $\begin{array}{l}\text { 蓄滞径流型 } \\
\text { Runoff detention }\end{array}$ & 通过收集雨水、汇聚过量地表径流, 缓解城市雨洪压力 & $\begin{array}{l}\text { 集雨池、塘和塘复合体、海绵 } \\
\text { 湿地 }\end{array}$ \\
\hline $\begin{array}{l}\text { 生物多样性维持型 } \\
\text { Biodiversity maintenance }\end{array}$ & $\begin{array}{l}\text { 为关键或当地特有物种提供适宜的生境条件; 为昆虫、两栖动物、爬 } \\
\text { 行动物、底栖动物、和水鸟提供迁徙途中的停歇地和避难所 }\end{array}$ & $\begin{array}{l}\text { 森林春池、草原坑洞恶穴湿地、 } \\
\text { 沙漠泉 }\end{array}$ \\
\hline $\begin{array}{l}\text { 储备水源型 } \\
\text { Water storage }\end{array}$ & 回充地下水, 储存雨水、洪水用于旱季的生活、灌溉、绿化用水 & $\begin{array}{l}\text { 岩溶洞穴湿地、蓄水池塘、水塘、 } \\
\text { 输水渠 }\end{array}$ \\
\hline $\begin{array}{l}\text { 景观游憩型 } \\
\text { Landscape and recreation }\end{array}$ & $\begin{array}{l}\text { 在营造湿地景观的基础上,配备亲水设施、建设游秝活动空间, 以及 } \\
\text { 相应的安全保障设施,可以满足人们游㮩和康养需求 }\end{array}$ & 社区小微湿地、城市滨河景观 \\
\hline $\begin{array}{l}\text { 生产型 } \\
\text { Production }\end{array}$ & 支持农业生产, 向人类提供食物、渔业、盐业产品 & $\begin{array}{l}\text { 稻田、藕塘、鱼塘、虾塘、苇塘, } \\
\text { 其他养殖塘,盐田 }\end{array}$ \\
\hline $\begin{array}{l}\text { 科普宣教型 } \\
\text { Environmental education }\end{array}$ & 提供自然教育的场所,传播湿地生态系统基本知识和湿地保护理念 & $\begin{array}{l}\text { 实验基地、自然学校里的小型 } \\
\text { 湿地 }\end{array}$ \\
\hline
\end{tabular}

\section{3 小微湿地的主导生态系统服务}

小微湿地具有独特的水文、地理特性和生物地球化学过程, 因此也提供了一些大型湿地无法提供的生态 系统服务。

\section{1 提供关键物种生境}

湿地是众多濒危野生动植物,特别是珍稀水禽的栖息、繁殖和越冬地。由于面积的限制, 小微湿地不可能 成为大型哺乳动物或大型水鸟永久的栖息地,但是却是某些特殊动物、植物的重要生境。 
两栖动物和爬行动物不一定需要大型的或植物区系多样的湿地, 小型的、结构简单的湿地通常对它们具 有更高的价值。小微湿地中的水体通常较浅,会随着季节变化淹水或干涸,水位变化增强了湿地的初级生产 力, 有利于旱生植物和水生植物同时存在 ${ }^{[38]}$, 为两栖动物和爬行动物提供相对充足的食物。因为一年中只有 部分时间有水, 不适合食肉性鱼类生存, 减少了捕食两栖动物卵和幼体的机会, 提高了两栖动物的存活率 ${ }^{[39] 。}$ 此外, 与周边湿地相连的某些小微湿地, 如河漫滩上的水塘、与地表水相连的沟渠等, 可为多种鱼类提供重要 的产卵和育苗场所 ${ }^{[2]}$ 。含钙和镁离子较高的岩溶洞穴湿地 (面积通常小于 $0.25 \mathrm{hm}^{2}$ ) 则是某些罕见的耐钙植 物的生存场所 ${ }^{[40]}$ 。

\section{2 生物迁移踏脚石}

在提供栖息地之外, 小微湿地还可增加景观的连通性来促进生物多样性的保护。随着如疏浚、排水和填 埋等人类活动加剧, 天然的大型湿地斑块逐渐破碎化, 影响了那些迁移能力不强的小型湿地动物。例如青蛙、

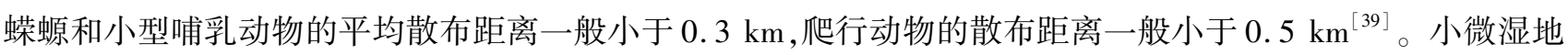
可以作为这些动物迁移过程中的 “踏脚石 (Stepping Stone)”, 提高动物在迁移中的存活率 ${ }^{[41]}$ (如图 1)。例如 北美豹蛙 (Lithobates pipiens) 和美洲牛蛙 (Lithobates catesbeianus) 习惯在水位较深的湿地越冬, 迁移到小微湿地 受食和繁殖, 然后返回深水栖息地冬眠 ${ }^{[37]}$ 。
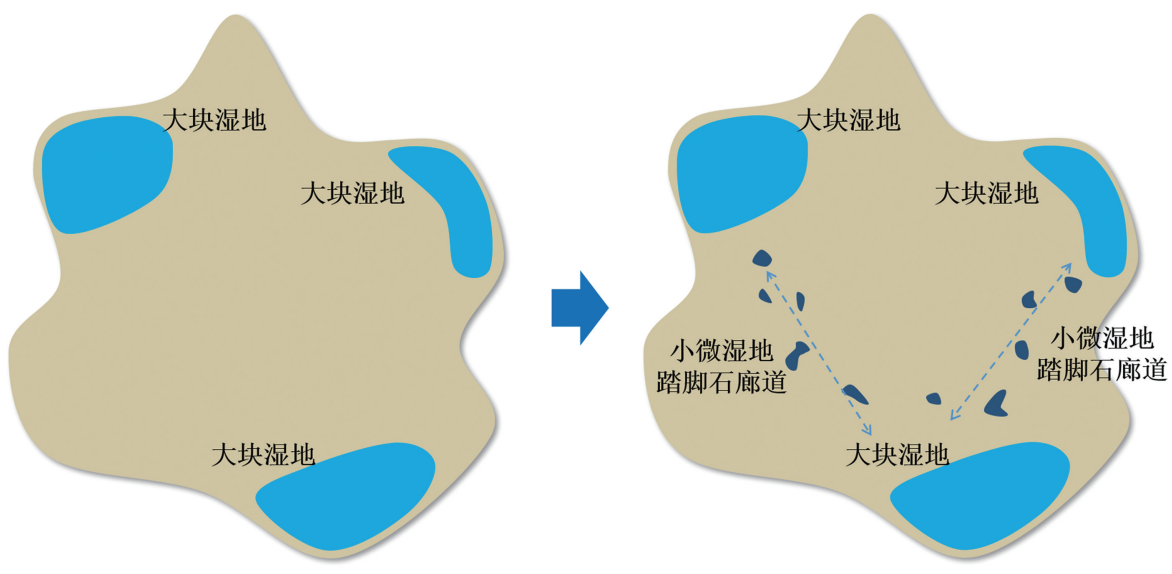

图 1 小微湿地作为生物迁移的“踏脚石”

Fig. 1 Small wetlands as stepping stones for biological migration

\section{3 支撑周围的食物链}

小微湿地也可以为周围生态系统中的动物如食肉昆虫、蛇、乌龟、鸟类和小型哺乳动物等提供食物 ${ }^{[42]}$, 提 高生态系统营养层级的复杂性, 使生态系统更为稳定。Moler 和 Franz 提出, 生活在 $1 \mathrm{hm}^{2}$ 小微湿地及其周围 的蟾蜍可以养活附近 $1000 \mathrm{hm}^{2}$ 的蛇类种群 ${ }^{[17]}$ 。Eldridge ${ }^{[43]}$ 发现小微湿地通常比大型湿地更容易解冻, 因此 在早春时期筑巢的雌鸟和倠鸟更容易在小型湿地中捕食到更多的无脊椎动物。

\section{4 水文与雨洪调节}

小微湿地被认为是湿地生态水文网络中的节点, 从纵向、横向、垂直和时间四个维度连接景观 ${ }^{[56]}$ 。与较 大面积的湿地相比, 小微湿地具有更小的内缘比, 意味着同等面积下, 小微湿地岸线更长。岸带区域是植物生 长密集区域, 因此小微湿地有更高的蒸散率, 多个小微湿地的累加作用在流域尺度上有可能更有效减少径 流 $^{[31]}$ 。如果流域上游存在多个小型湿地, 流域下游的湿地能更有效地衰减洪水 ${ }^{[44]}$ 。在湿地恢复工程中, 如 果限于场地原因只能在流域下游修建湿地, 那么沿着河道修建一些小微湿地, 比单独地建造一个大型湿地更 能削减洪水径流 ${ }^{[45]}$ 。例如, Evrard 等在比利时的研究表明, 修建小型蓄水性池塘, 可以减少流域 $40 \%$ 的峰值 流量 ${ }^{[46]}$ 。Schmied ${ }^{[4]}$ 的研究表明, 小微湿地在均化洪水的同时, 能够在干旱时期为流域提供基流。世界野生 动物基金 (World Wildlife Fund, WWF) 和湿地国际 (Wetland International, WI) 在莱茵河流域, 通过在泛洪区 
修复或新建小微湿地 (报告中称为 Nature Sponges, 天然海绵) 来实现雨洪管理,初步评估结果显示当地向莱茵 河输人的支流的洪峰降低了 $5 \%-8 \%$ 。

在城市区域,小微湿地是为数不多保持渗透性的区域,能将雨洪水渗透到地下。海绵城市就是充分考虑 了城市雨洪与湿地的密切关系, 通过设置引水装置, 收集城市雨洪水并进行净化, 既缓解了城市内涝的发生, 又解决了景观中的水体平衡和水质问题 ${ }^{[48]}$ 。

\section{5 净化水质}

湿地的净化功能与植物配置、水力停留时间、基质类型等要素较为相关。有研究表明净化型小微湿地的 单位面积净化效率可能要高于大型湿地 ${ }^{[2]}$ 。小微湿地通过调控可具有更动态变化的水位, 好氧 (高地) 和厌 氧 (湿地) 的土壤条件能够交互出现, 从而增强土壤中微生物的反硝化过程 ${ }^{[49]}$ 。例如, Capps 等的研究发现美 国缅因州中部的春池湿地是调落物分解、反硝化和酶活性最为活跃的区域 ${ }^{[50]}$ 。

沟渠类型的小微湿地也具有很强的水质净化功能, 通常作为缓解农业面源污染的缓冲区域 ${ }^{[51]}$ 。最具有 代表性的一类水质净化型小微湿地是人工处理湿地, 因其面积小、使用灵活、运行成本低等特点, 被广泛应用 于生活污水、牲畜粪便、餐饮油脂污水的处理中 ${ }^{[52]}$ 。实践表明,多个面积较小的处理单元级联耦合而成的人 工处理湿地, 通常具有更高的处理效率 ${ }^{[53]}$ 。

\section{6 景观游憩与自然教育}

湿地能够为人类提供亲近自然的体验与游㮩空间,如公园水景营建、城市河道修复、人居环境改善等 ${ }^{[54]}$ 。

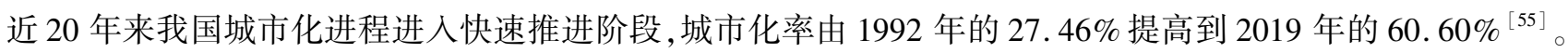
随着城市发展日渐成熟,城市范围内可以用作建设湿地景观的生态空间变得越发有限, 小微湿地的出现满足 了城市居民对多样游㕷空间的需求，同时其也成为了各类城市用地之间的生态缓冲区域。任全进 ${ }^{[10]}$ 和高利 雪 ${ }^{[56]}$ 指出在各类城市绿地建设中恢复与营造小微湿地, 是未来城市景观建设的新方向。

此外, 还可以通过展示小微湿地生态系统、多样的湿地动植物群落, 水质净化效果等, 为自然教育提供材 料和实验基地。在北京市野生动物救护与繁育中心依托园区内的小型人工处理湿地开展了丰富的湿地宣教 活动, 成为独特的户外课堂, 展示了湿地的生态功能, 传播了湿地保护理念。

\section{7 其他生态系统服务}

除此之外，小微湿地还能提供储蓄水源、生产供给、调节局地小气候等服务。在水源贫㾑区域,积水的露 岩、溶石孔等可以为当地居民提供临时水源 ${ }^{[57]}$ 。某些特定类型的小微湿地, 如稻田、藕塘、鱼塘、苇塘等可以 向人类提供食物、原材料等各种直接和间接可利用资源。一些复合式小微湿地产业模式,如江苏省潮间带滩 涂贝类养护基地、西溪湿地柿基鱼塘、珠江三角洲泡沼基塘等经过实践证明能够优化湿地资源利用,实现湿地 可持续发展 ${ }^{[8-59]}$ 。此外,小微湿地可以通过影响周围的气温和湿度来调节局地小气候 ${ }^{[60]}$ 。

与此同时, 小微湿地也可能也会带来一些负面影响。人工处理湿地在净化污水的过程中会生产和排放甲 烷 $\left(\mathrm{CH}_{4}\right)$ 和氧化亚氮 $\left(\mathrm{N}_{2} \mathrm{O}\right)$ 等温室气体 ${ }^{[61]}$; 净水塘和雨水蓄留型湿地, 其滞留的水体和茂密的植被为蚊虫提 供了杽生场所, 会为当地居民带来健康风险 ${ }^{[62]}$ 。

\section{4 展望与建议}

2018 年,《湿地公约》第十三次缔约国大会接受并通过了由中国提交的“小微湿地保护管理( Conservation and Management of Small Wetland)”决议草案, 呼吁各缔约国关注小微湿地发挥的重要生态功能, 以及在气候 变化和城市化发展中面临的日益增长的威胁风险。在该项决议的指导下, 针对小微湿地的调查、保护和修复 将成为全球未来湿地管理工作的一项重要内容。

我国的湿地保护方针经历了从优先性保护到全面保护的转变,并逐渐向精细化管理发展。2016 年底,国 务院办公厅印发的《湿地保护修复制度方案》提出 “将全国所有湿地纳人保护范围”, “实行湿地面积总量控 制”, 通过 “先补后占, 占补平衡” 的办法确保湿地面积不减少, 湿地质量不下降 ${ }^{[63]}$ 。在随后各省出台的配套 
落实文件中, 部分省市提出了专门针对小微湿地保护管理的政策导向, 如北京市要求建立小微湿地台账, 并打 造以小微湿地为主的城市湿地。浙江省等也开始探索小型池塘、沟渠、河浜的治理和恢复。小微湿地的恢复 与建设, 在某种程度上契合了目前高密度人口国家和地区生态建设的重要需求, 在区域城市化水平高, 水资 源、空间资源和土地资源紧缺的情况下,广泛推进小微湿地的恢复建设,能够精准补充区域生态本底资源的不 足和生态空间的空缺。

在小微湿地恢复与建设蓬勃发展的契机下, 未来应加强小微湿地机理研究, 关注小微湿地生物地球化学 循环和关键水文生态过程,探究面积、形状、地理区位与水文联通性等要素如何影响小微湿地的生态系统服 务; 研发提高空间分辨率的遥感技术, 提升小微湿地的识别精度。同时,建议将小微湿地建设与管理与现行的 湿地保护体系有机结合。针对小微湿地开展专项资源调查, 了解小微湿地的资源总量和分布情况。将小微湿 地纳人湿地监测体系, 了解小微湿地动态变化情况。并进一步将小微湿地建设与城市双修、乡村人居环境综 合整治等深度整合, 通过建设一批农村分散型污染处理湿地、城市海绵湿地、城市景观游憩湿地等具有特殊主 导功能的小微湿地, 促进生态宜居城市和美丽乡村建设。最后, 应尽早制定国家、行业及地方小微湿地标准, 指导小微湿地恢复与建设的科学开展。

\section{参考文献 (References) :}

[ 1 ] Ramsar Convention on Wetlands. Global Wetland Outlook: State of the World's Wetlands and their Services to People. Gland, Switzerland: Ramsar Convention Secretariat, 2018.

[ 2 ] Adamus P. Wetland functions: not only about size. National Wetlands Newsletter, 2013, 35(5): 18-19, 25-25.

[ 3 ] Ramsar Convention on Wetlands. About the convention on wetlands. [2020-04-08]. https://www. ramsar. org.

[ 4 ] 国家林业和草原局. 绿色发展 70 年之自然保护区数据有话说. [2020-04-08 ]. http://www. forestry. gov. cn/main/4462/20191104/ 110911392530674. html.

[ 5 ] Burgin S. 'Mitigation banks' for wetland conservation: a major success or an unmitigated disaster? Wetlands Ecology and Management, 2010, 18 (1) : $49-55$.

[ 6 ] Williams P, Biggs J, Crowe A, Murphy J, Nicolet P, Weatherby A, Dunbar M. 2010. Countryside survey. http://www. europeanponds. org/ publications/documents-on-ponds/.

[ 7 ] Dahl T E. Status and trends of prairie wetlands in the United States 1997 to 2009. US Fish and Wildlife Service. [2020-05-10]. https://library. villanova. edu/Find/Record/1669384/Details.

[ 8 ] Biggs J. Ponds, pools and lochans: guidance on good practice in the management and creation of small waterbodies in Scotland. [2020-04-08]. https://www. sepa. org. uk/media/151336/ponds_pools_lochans. pdf.

[ 9 ] 赵晖, 陈佳秋, 陈釡, 熊依依, 安树青. 小微湿地的保护与管理. 湿地科学与管理, 2018, 14(4): 22-26.

［10］任全进，季茂晴，于金平. 小微湿地的作用及营造方法. 现代农业科技，2015，13：225-225，230-230.

[11] Schmied H M, Helmschrot J, Flügel W A. Hydrological functioning of a small wetland patch within a headwater environment in Thuringia, Germany//Proceedings of the 3rd Annual Meeting of the European Chapter of the Society of Wetland Scienitsts. Tartu, Estonia: Publicationes Instituti Geographici Universitatis Tartuensis, 2008.

[12] Nolan R H, Vesk P A, Robinson D. Recovery potential of microwetlands from agricultural land uses. Ecological Management \& Restoration, 2018, $19(1): 81-84$.

[13] Haig S M, Mehlman D W, Oring L W. Avian movements and wetland connectivity in landscape conservation. Conservation Biology, 1998,12 (4) : 749-758.

[14] 关博. 吉林长白山国家级自然保护区野生动物保护成效与适宜规模研究 [D]. 北京: 北京林业大学, 2013.

[15] Trochlell P, Bernthal T. Small Wetlands and the Cumulative Impacts of Small Wetland Losses: A Synopsis of the Literature. Madison, WI: Wisconsin Department of Natural Resources, 1998.

[16] Russell K R, Guynn Jr D C, Hanlin H G. Importance of small isolated wetlands for herpetofaunal diversity in managed, young growth forests in the Coastal Plain of South Carolina. Forest Ecology and Management, 2002, 163(1-3) : 43-59.

[17] Moler P E, Franz R. Wildlife values of small, isolated wetlands in the southeastern coastal plain//Odum R R, Riddleberger K A, Ozier J C, eds. Proceedings of the Third Annual Southeastern Nongame and Endangered Wildlife Symposium. Atlanta, Georgia: Georgia Department of Natural Resources, 1987. 
[18] McKenna O P, Mushet D M, Rosenberry D O, LaBaugh J W. Evidence for a climate-induced ecohydrological state shift in wetland ecosystems of the southern prairie pothole region. Climatic Change, 2017, 145(3/4) : 273-287.

[19] Elliott C R. Mapping Nebraska wetlands. NEBRASKAland, 1991, 69(5): 37-41.

[20] Gersib R A. Nebraska wetlands priority plan for inclusion in the 1991-1995 Nebraska State Comprehensive Outdoor Recreation Plan. Lincoln, NE, USA: Nebraska Game and Parks Commission, 1991.

[21] McCulloch G, Aebischer A, Irvine K. Satellite tracking of flamingos in southern Africa: the importance of small wetlands for management and conservation. Oryx , 2003, $37(4): 480-483$.

[22] Ramsar Convention on Wetlands. Republic of Korea names small urban wetland. [2012-06-22]. https://www. ramsar. org/news/republic-ofkorea-names-small-urban-wetland.

[23] Wassen M J, Olde Venterink H, Lapshina E D, Tanneberger F. Endangered plants persist under phosphorus limitation. Nature, 2005 , 437 (7058) : 547-550.

[24] Wilpiszewska I, Kloss M. Wetland patches (potholes) in a mosaic landscape (Masurian Lakeland, Poland) : floristic diversity and disturbance. Polish Journal of Ecology, 2002, 50(4) : 515-525.

[25］国家林业局. 全国湿地资源调查技术规程（试行). 林湿发 [ 2008 ] 265 号（2019-01-12). http://www. shidi. org/sf _ 822E186D9DE944DA9642D98D46342F35_151_wuzi0. html.

[26] Semlitsch R D, Bodie J R. Are small, isolated wetlands expendable? Conservation Biology, 1998, 12(5): 1129-1133.

[27] 崔丽娟, 雷茵茹. 《北京市湿地保护条例》解读. 北京: 中国林业出版社, 2019.

[28] Robinson G R, Quinn J F. Habitat fragmentation, species diversity, extinction, and design of nature reserves//Jain S K, Botsford L W, eds. Applied Population Biology. Dordrecht: Springer, 1992: 223-248.

[29] 徐基良, 崔国发, 李忠. 自然保护区面积确定方法探讨. 北京林业大学学报, 2006, 28(5): 129-132.

[30］刘红玉, 吕宪国, 张世奎. 湿地景观变化过程与累积环境效应研究进展. 地理科学进展, 2003, 22(1): 60-70.

[31] Millar J B. Shoreline-area ratio as a factor in rate of water loss from small sloughs. Journal of Hydrology, 1971, 14(3/4) : 259-284.

[32] 傅伯杰, 陈利顶, 马克明, 王仰麟. 景观生态学原理及应用(第二版). 北京: 科学出版社, 2011.

[33] 崔国发, 郭子良, 王清春, 邢韶华, 张建亮. 自然保护区建设和管理关键技术. 北京: 中国林业出版社, 2018.

[34] Golden H E, Creed I F, Ali G, Basu N B, Neff B P, Rains M C, McLaughlin D L, Alexander L C, Ameli A A, Christensen J R, Evenson G R, Jones C N, Lane C R, Lang M. Integrating geographically isolated wetlands into land management decisions. Frontiers in Ecology and the Environment, 2017, 15(6): 319-327.

[35] Tiner R W. Geographically isolated wetlands of the United States. Wetlands, 2003, 23(3) : 494-516.

[36] Boulton A, Brock M, Robson B, Ryder D, Chambers J, Davis J. Australian Freshwater Ecology: Processes and Management. 2nd ed. Hoboken: Wiley-Blackwell, $2014: 25-31$.

[37] Mushet D M, Euliss Jr N H, Chen Y J, Stockwell C A. Complex spatial dynamics maintain northern leopard frog (Lithobates pipiens) genetic diversity in a temporally varying landscape. Herpetological Conservation and Biology, 2013, 8(1) : 163-175.

[38 ] Jeffries M J, Epele L B, Studinski J M, Vad C F. Invertebrates in temporary wetland ponds of the temperate biomes//Batzer D, Boix D, eds. Invertebrates in Freshwater Wetlands: An International Perspective on Their Ecology. Cham: Springer, 2016 : $105-139$.

[39] Machmer M. Small Wetland Literature Review and Mapping. Nelson, BC: Pandion Ecological Research Ltd, 2004.

[40] Wolfe B E, Weishampel P A, Klironomos J N. Arbuscular mycorrhizal fungi and water table affect wetland plant community composition. Journal of Ecology, 2006, 94(5) : 905-914.

[41] Zamberletti P, Zaffaroni M, Accatino F, Creed I F, De Michele C. Connectivity among wetlands matters for vulnerable amphibian populations in wetlandscapes. Ecological Modelling, 2018, 384: 119-127.

[42] Richter K O, Azous A L. Amphibian occurrence and wetland characteristics in the Puget Sound Basin. Wetlands, 1995, 15(3): 305-312.

[43] Eldridge J. Aquatic invertebrates important for waterfowl production//Waterfowl Management Handbook. Washington, DC, USA: U. S. Fish and Wildlife Service Fish and Wildlife Leaflet, 1990.

[44] DeLaney T A. Benefits to downstream flood attenuation and water quality as a result of constructed wetlands in agricultural landscapes. Journal of Soil and Water Conservation, 1995, 50(6): 620-626.

[45] Knight R L. Ancillary benefits and potential problems with the use of wetlands for nonpoint source pollution control. Ecological Engineering, 1992, $1(1 / 2): 97-113$.

[46] Evrard O, Bielders C L, Vandaele K, Van Wesemael B. Spatial and temporal variation of muddy floods in central Belgium, off-site impacts and potential control measures. CATENA, 2007, 70(3): 443-454.

[47] WWF, WI. Restoration of the Marshes in the Valleys of the Middle Mountains of the Rhine Basin for Flood and Drought Risk Reduction- ' The 
Sponges Approach'. (2017-11-01) [2020-03-24]. https://www. stroming.nl/sites/default/files/2017-12/20171114_sponges_read_3.pdf.

[48］孟永刚, 王向阳, 章茹. 基于“海绵城市”建设的城市湿地景观设计. 生态经济, 2016, 32(4): 224-227.

[49] Wray H E, Bayley S E. Denitrification rates in marsh fringes and fens in two boreal peatlands in Alberta, Canada. Wetlands, 2007, 27 (4): 1036-1045.

[50] Capps K A, Rancatti R, Tomczyk N, Parr T B, Calhoun A J K, Hunter Jr M. Biogeochemical hotspots in forested landscapes: the role of vernal pools in denitrification and organic matter processing. Ecosystems, 2014, 17(8): 1455-1468.

[51] Blackwell M S A, Hogan D V, Pinay G, Maltby E. The role of buffer zones for agricultural runoff//Maltby E, Barker T, eds. The Wetlands Handbook. Chichester: Wiley-Blackwell, 2009.

[52] 刘冬, 张慧泽, 徐梦佳. 我国人工湿地污水处理系统的现状探析及展望. 环境保护, 2017, 45(4): 25-28.

[53] 崔丽娟, 李伟, 张岩, 张曼扸, 王义飞, 赵欣胜, 李胜男. 复合人工湿地对水禽污染废水的净化效果. 生态科学, 2011,30 (4) : 446-453.

[54] 江梅. 居住区湿地景观的营造. 现代园艺, 2014, 3: 108-108.

[55] 国家统计局. 中国统计年鉴 2019. 北京: 中国统计出版社, 2019 .

[56] 高利雪. 城市酒店小微湿地景观设计研究 $[\mathrm{D}]$. 北京: 中国林业科学研究院, 2017.

[57] Fitzsimons J, Ashe C. Some recent strategic additions to Victoria's protected area system 1997-2002. Victorian Naturalist, 2003, 120 ( 3 ) : 98-108.

[58］王艳霞, 鞠美庭. 我国湿地保护与湿地产业发展策略探讨. 生态经济, 2008, 1: 132-136.

[59］王世岩，杨永兴，杨波. 我国湿地农业可持续发展模式探析. 中国生态农业学报, 2005, 13(2)：176-178.

[60] 朱浩楠, 刘晓申, 孙佳, 王颖, 廖代强, 周杰. 湿地公园对局地气候舒适性影响的数值试验. 自然资源学报, 2019, 34(2): 412-423.

[61] Hefting M M, Bobbink R, De Caluwe H. Nitrous oxide emission and denitrification in chronically nitrate-loaded riparian buffer zones. Journal of Environmental Quality, 2003, 32(4): 1194-1203.

[62] 赵红红, 吕慧. 低影响开发中利于蚊虫防制的湿地规划设计方法. 西南师范大学学报: 自然科学版, $2017,42(5): 83-89$.

[63] 崔丽娟, 张骁栋, 张曼胤. 中国湿地保护与管理的任务与展望一一对《湿地保护修复制度方案》的解读. 环境保护, 2017,45 (4): 13-17. 